BIOTROPIA No. 6, 1992/1993: 33-44

\title{
EFFECTS OF THE HEAVY METAL, ZINC, ON THE FRESHWATER FISH TILAPIA NILOTICA L.
}

\author{
VIRGINIAS. CARING \\ Institute of Biology, University of the Philippines, \\ Diliman, Quezon City, Philippines
}

\begin{abstract}
Gills, gonads, and blood of Tilapia nilotica exposed to different concentrations of zinc sulfate $\left(\mathrm{ZnSO}_{4}\right.$. $7 \mathrm{H}_{2} \mathrm{O}$ ) exhibited histological effects. Gills of posthatch larvae exposed chronically for 21 days to 2 ppm zinc sulfate and fingerlings to $10 \mathrm{ppm}$ sublethal zinc concentrations exhibited hyperplasia that resulted in fusion of adjacent secondary gill lamellae. The same effects were observed in 4-hour short-term exposure to $30 \mathrm{ppm}$ lethal dose.

Posthatch larvae subjected to 2 and 5 ppm sublethal levels of zinc for 30 days retained undifferentiated gonads with differentiation with oogonial proliferation. Ovaries of control fish demonstrated healthy oocyte growth and other normal histological features after 57 days. In contrast, ovaries in treated groups exhibited excessive amounts of connective tissue, hyperemia and markedly reduced oocyte number. Oocytes had wavy irregular surface outlines. Deviation from normal was observed to be dose dependent. In juvenile tilapia, spermatogenesis was observed in control testes. Testes of zinc-exposed fish, on the other hand, remained immature. Hyperemia was markedly pronounced in both testes and ovary after 90 days exposure to zinc.

Blood of Tilapia nilotica fingerlings exposed to sublethal concentrations of 2, 5, and $10 \mathrm{ppm}$ zinc for 30 , 60 , and 90 days exhibited anisocytosis and poikilocytosis. There was an increase in hematocrit values in zinc-reared fish which, however, reverted to control/near control levels at day 90 . Hemoglobin values were inversely proportional to the level of zinc in the rearing water. The marked reduction in hemoglobin values in fish reared at the higher zinc concentrations of 5 and $10 \mathrm{ppm}$ suggests the development of some degree of anemia which is also supported by the observations of anisocytosis and poikilocytosis.
\end{abstract}

\section{INTRODUCTION}

Heavy metal contamination of aquatic environments has become a current serious problem because of increased industrialization. In the Philippines, data gathered by the National Environmental Pollution Commission (NEPC 1980) on eleven river systems and of researches monitoring levels of heavy metals in fishes indicate high concentrations of these substances in aquatic bodies (NEPC 1980; PCARRD 1982). Compared to seas and oceans, fresh water environments are more vulnerable to pollution stress inasmuch as they are smaller systems and have more limited numbers and kinds of organisms. Pollution of lakes and rivers, thus, pose alarming dangers to aquatic life, as for example to fish.

One fresh water fish which is presently being studied intensively insofar as its response to heavy metals contamination, is Tilapia nilotica L. Economically 
important as a poor man's protein source, it is easily available and is a hardy fish species. Thus, it is expected that less sturdy fishes would exhibit any effect manifested by this particular species. Most of the studies that will be reported in this paper deal with the effects of zinc on posthatch larvae or fry of Tilapia nilotica. This stage of development, is a good investigative material since a number of organs, e.g., the gonads have not completed full development and differentiation. The earlier developmental stages are interesting subjects, but in T. nilotica they are not too exposed to the environment inasmuch as they brood in the tilapia mother's mouth and are hence semi-protected.

\section{MATERIALS AND METHODS}

Preliminary $96 \mathrm{hr} \mathrm{LD}^{50}$ determination was performed to obtain the approximate sublethal levels of zinc on the T. nilotica stage that would be tested. During the four days period the fish were kept in aerated water with different concentrations of $\mathrm{ZnSO}_{4}$ and were starved to minimize the elimination of the metal together with waste products.

Dechlorinated tap water was used in all tests. Hardness, alkalinity, and $\mathrm{pH}$ readings were taken twice a week on the test water in the aquarium. Hardness and alkalinity were determined by titration method (APHA 1971). Temperature was monitored daily.

Zinc sulphate $\left(\mathrm{ZnSO}_{4} \cdot 7 \mathrm{H}_{2} \mathrm{O}\right.$, AR Merck $\left.{ }^{\circledR}\right)$ was dissolved in deionized water and acidified to $\mathrm{pH} 2$ with nitric acid $\left(\mathrm{HNO}_{3}\right)$. The plastic jars with 3.01 test water were spiked with zinc solution to bring the concentration to the desired level.

Posthatch fry of T. nilotica were obtained from a single source and acclimated in well aerated dechlorinated tap water for 7 days prior to experimentation. Chronic as well as acute exposures to zinc were done at different time exposures. The organs to be reported on are the gills, gonads, and blood.

For light microscopy, tissues were dehydrated in a series of graded ethyl alcohol, cleared in cedarwood oil and xylene, infiltrated and embedded in paraffin, and cut in $\mathrm{AO}^{\circledR}$ rotary microtome. Paraffin sections of 7 urn thickness were stained with Hematoxylin-Eosin and mounted in Entellan ${ }^{\circledR}$ mounting medium.

Resin sections were also done. Tissues dissected were fixed in $2.5 \%$ glutaraldehyde in phosphate buffer, $\mathrm{pH} 7.2$, followed by post-fixation in $1 \%$ osmium tetroxide. The samples were dehydrated in ethanol and propylene oxide, embedded in Araldite $^{\circledR}$, sectioned 1 - 2 urn thick with Carl Zeiss ${ }^{\circledR}$ ultratome, stained with $1 \%$ toluidine blue and examined under the light microscope. Ultrathin sections were stained with uranyl acetate and lead citrate for electron microscopy. 
For blood parameters, fingerlings were reared in zinc concentrations of 2, 5, and 10 ppm for 30, 60, and 90 days (Cariño and Casauay 1991). Blood samples were collected by gill puncture using heparinized capillary tubes and analyzed for haematocrit and haemoglobin content using capillary method (Hesser 1960) and ALS Biochemical Haemoglobin Procedure ${ }^{\circledR}$, USA, respectively. Blood smears were made and stained with Giemsa for erythrocyte morphology.

\section{RESULTS AND DISCUSSION}

\section{Effects on Gills}

In tilapia fingerlings exposed to $10 \mathrm{ppm}$ and $20 \mathrm{ppm}$ zinc sulfate for 21 days, the main effect was hyperplasia of the primary gill epithelia resulting in fusion of adjacent secondary lamellae (Cariño \& Puzon 1986). Hyperplasia was noted in all treatment groups, both short-term exposure (4 hours) to $30 \mathrm{ppm}$ lethal concentration of zinc and long-term treatment (21 days) to $20 \mathrm{ppm}$ chronic and $10 \mathrm{ppm}$ sublethal levels of the metal (Figs. 1 \& 2). Extensive cell proliferation was noted along the entire length of the gill filaments of fish exposed to the highest zinc concentration

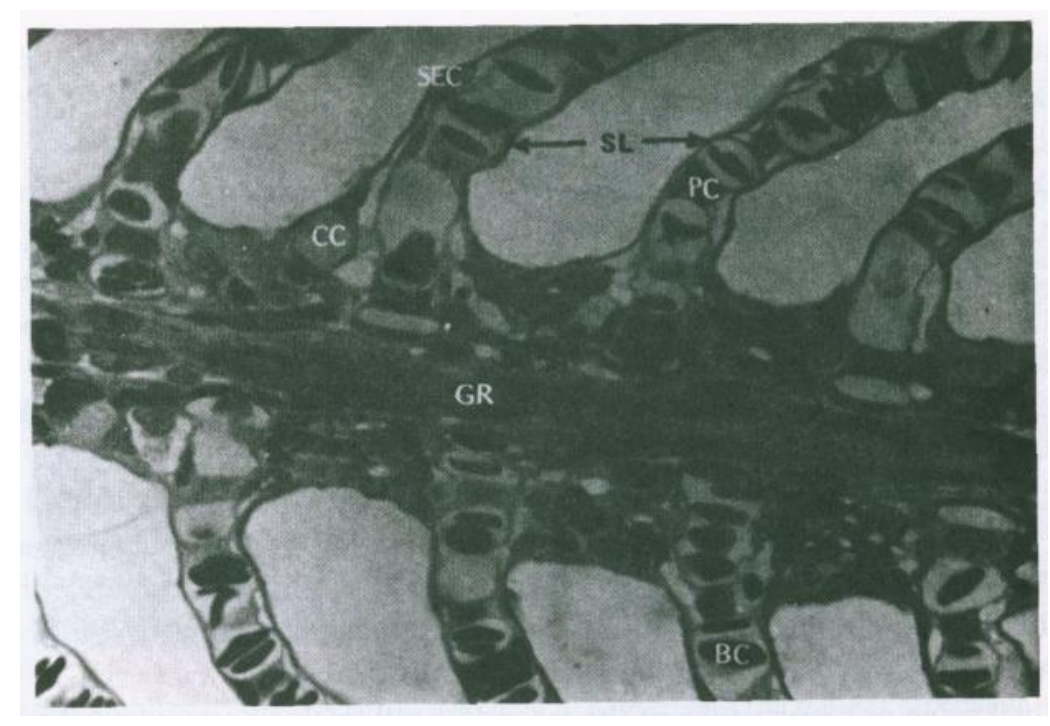

Figure 1. Longitudinal section of control gill filament. CC, chloride cell; SEC, secondary epithelial cell; SL, secondary lamellae; PC, pillar cell; BC, blood cell; GL, gill ray. X960. 


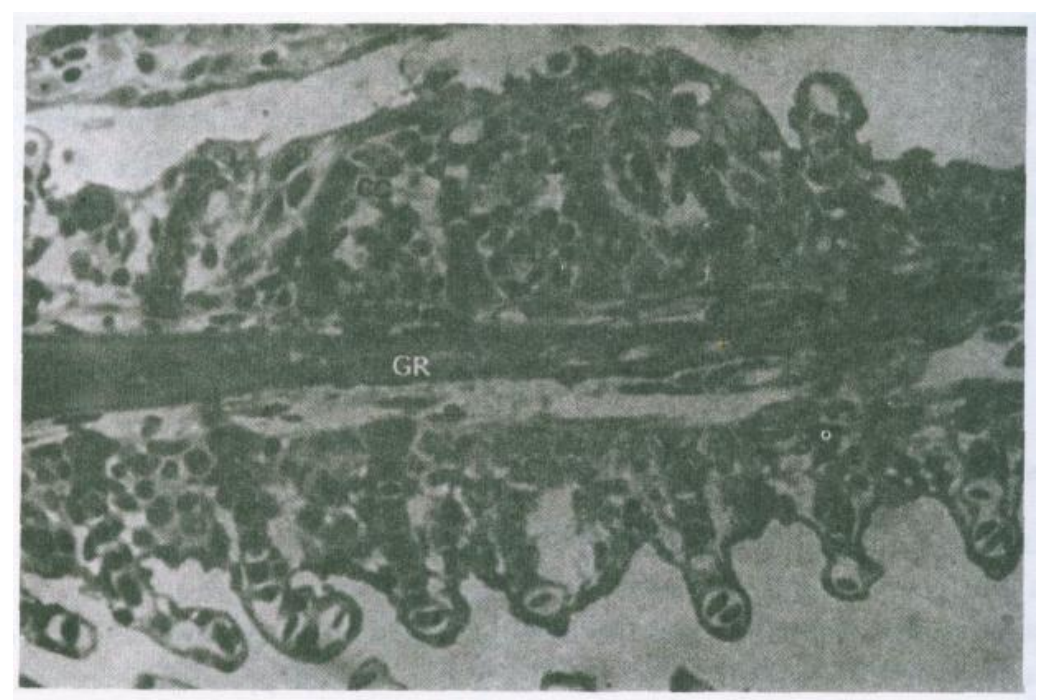

Figure 2. Longitudinal section of gill filament from 10-ppm exposed fish showing fusion of adjacent secondary gill lamellae. CC, chloride cell; OR, gill ray. X480.

used, $30 \mathrm{ppm}$. The overall effect of the zinc salt on the gill structure is the decrease in surface area which would otherwise make for an efficient transport of oxygen in the blood.

Other investigations showed that chemically induced hyperplasia of the primary gill epithelia is generally due to the increase in the number of chloride cells (Ahuja 1970; Crespo 1981; Tuurala \& Soivio 1982; Crespo 1984). Zinc was particularly shown to induce proliferation of the chloride cells in the dogfish Synliorhinus canicula (Crespo 1981). Increase in chloride cells have likewise been noted in the study of Cariño \& Puzon (1986) with T. nilotica fingerlings. This indicates to invigorate osmoregulatory capacities.

Chloride cells are large salt secretory cells (Karnaky et al. 1977) found at the base of the secondary gill filament and believed to be responsible for osmoregulation (Karnaky 1980; Laurent \& Dunel 1980). They have been shown to excrete univalent ions, though they might also be able to excrete bivalent ions (Ahuja 1970). Na-K-ATPase is the major enzyme found in chloride cells.

Thickening or hypertrophy of the secondary gill epithelia was a less observable effect of zinc exposure in T. nilotica fingerlings. This was observed with $20 \mathrm{ppm}$ treatment (Figs. 3 \& 4). 


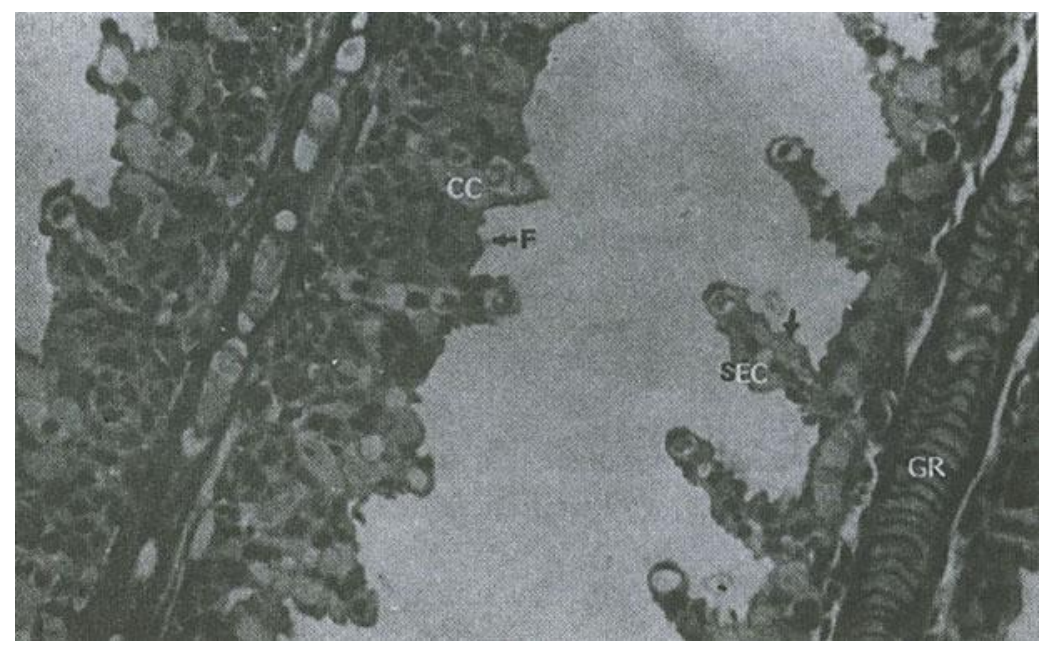

Figure 3. Longitudinal section of gill filament from 20-ppm exposed fish showing fusion (F) of secondary gill lamellae and hypertropy (arrow) of secondary epithelial cell. CC, chloride cell; SEC, secondary epithelial cell; GR, gill ray. X480.

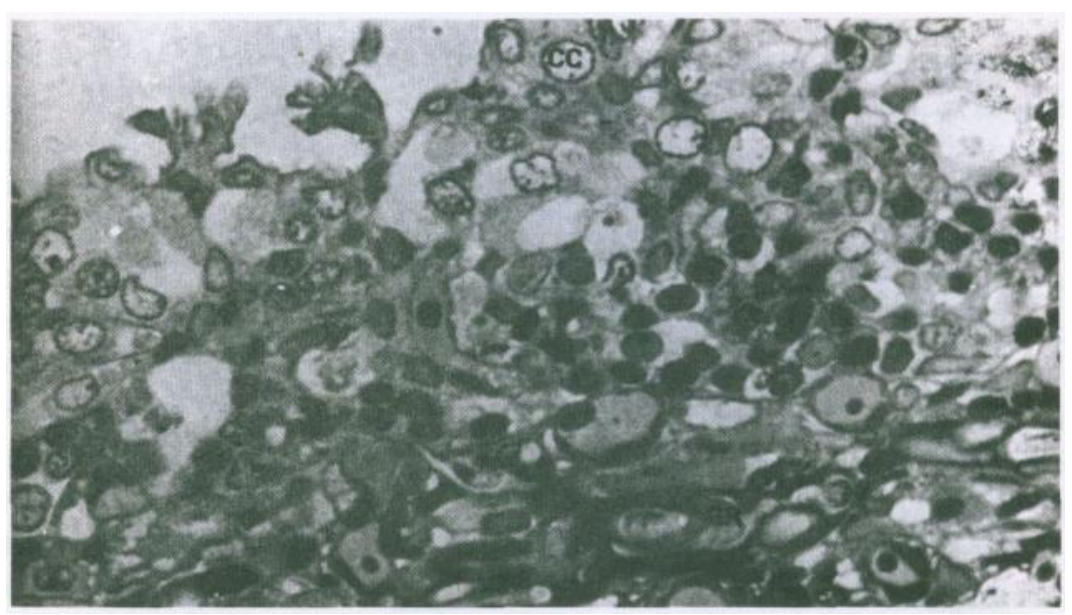

Figure 4. Longitudinal section of gill filament from 20-ppm exposed fish showing hyperplasia of chloride cell and fusion of secondary gill lamellae. CC, chloride cell; PC, pillar cell; BC, blood cell; GR, gill ray. X960. 
Hypertrophy of secondary gill epithelia has been reported as a response of fish to industrial pollutants. Hughes et al. (1979) noted that there was increase in the volume of secondary epithelia in nickel exposed Salmo gairdneri. Chromium has similar effect on the secondary epithelia of this species (Putte et al. 1981). Tuurala and Soivio (1982) observed that excessive hypertrophy of the secondary epithelial cells was induced by sublethal exposure of $S$. gairdneri to dihydroabietic acid, a major kraft pulping effluent (Leach \& Thakore 1973). Similar results have been obtained with exposure of Chanos chanos fingerlings to ammonia (Cruz \& Enriquez 1982).

Secondary lamellar hypertrophy increases the diffusing distance from the surrounding water to capillaries, but decreases the respiratory dead volume between the secondary lamellae and, thus, would compensate for the increase in the diffusion distance (Tuurala \& Soivio 1982).

Histological observations indicate that zinc impairs gaseous exchange in fishes by increasing diffusion distance and decreasing absorption surface area.

Electron microscopic structure of the secondary lamella of control fish is shown in Fig. 5. The lamellar blood sinus is large and circular in outline. The pillar cell and its nucleus is very distinct. Fish exposed to 2 ppm zinc for 21 days were observed to have lamellar blood sinus dilation and epithelial lifting of the secondary gill lamella (Fig. 6). Detachment of pillar cell from the epithelium occurred at $20 \mathrm{ppm}$ zinc exposure. Epithelial lifting results in the enlargement of the non-tissue spaces.

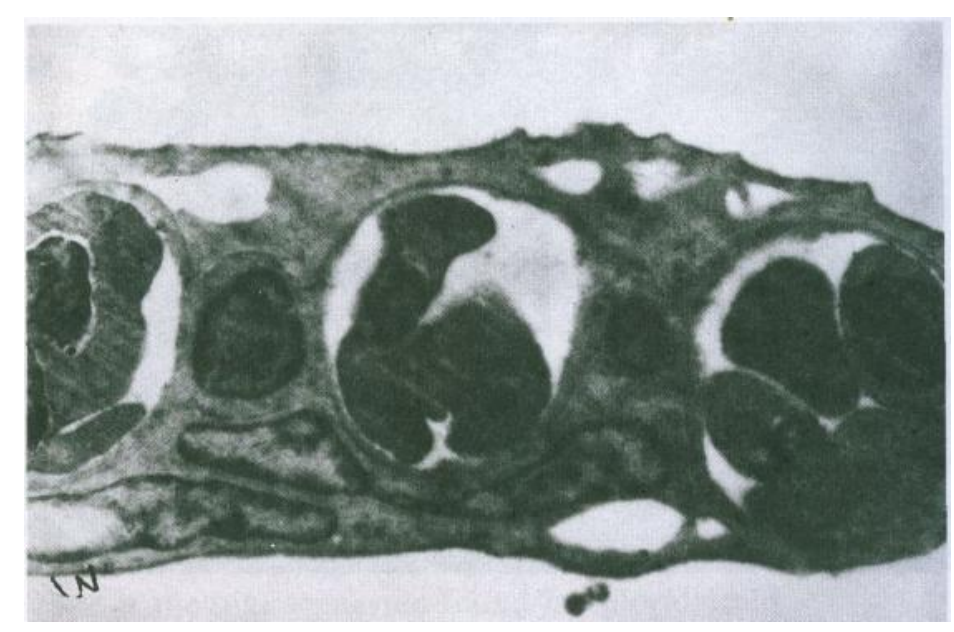

Figure 5. Electron micrograph of control secondary gill lamellae. X5000. 


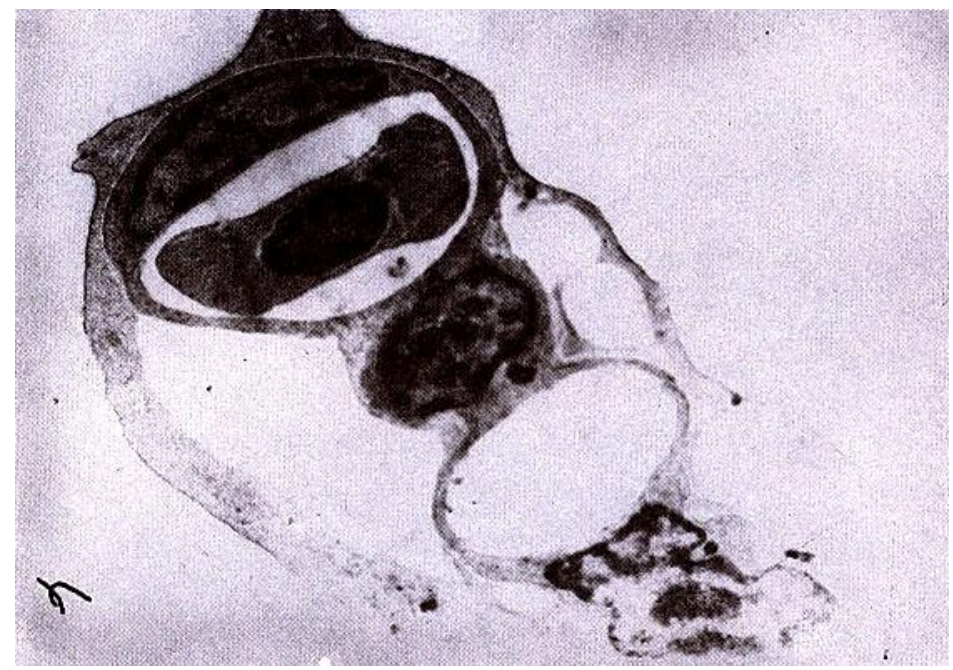

Figure 6. Electron micrograph of gill lamellae from 2-ppm exposed fish showing dilated blood sinus epithelial lifting. X5000.

\section{Effect on the Gonads}

Gonads of 30-day posthatch control fry exhibited gonial multiplication (Cariño \& Cruz 1990). No distinction can yet be made as to whether the gonad is testis or ovary. In contrast, all experimental fish reared for 30 days in three zinc concentrations had gonads that contained only primordial germ cells. Gonial multiplication was delayed. In fish harvested after 57 days in culture, oocyte growth is observed in both control and zinc-treated fish (Figs. 7a, b). A notable difference is the presence of promiscuous and dilated blood vessels densely filled with blood cells in the ovaries of zinc-treated fish. Oocytes of zinc-treated fish have more nucleoli than control fish. A number of these nucleoli-studded nuclei bear on one side a quarter moon-shaped region of intensely darkly stained material which is most probably extruded RNA. Accumulation of maternal RNA is characteristic of most growing oocytes. Graded distinctions between ovaries treated with 2, 5, and 10 ppm appear inconspicuous. Tests of 57-day reared control and zinc-treated fish showed spermatogonial multiplication. As noted by Casauay \& Carifio (1988), spermatogenesis in Tilapia nilotica commences later than oogenesis. Testes of juvenile $T$. nilotica showed spermatogenic stages. In contrast, zinc-treated fish showed delay in spermatogenesis (Figs. 8a, b). 
BIOTROPIA No. 6, 1992/1993
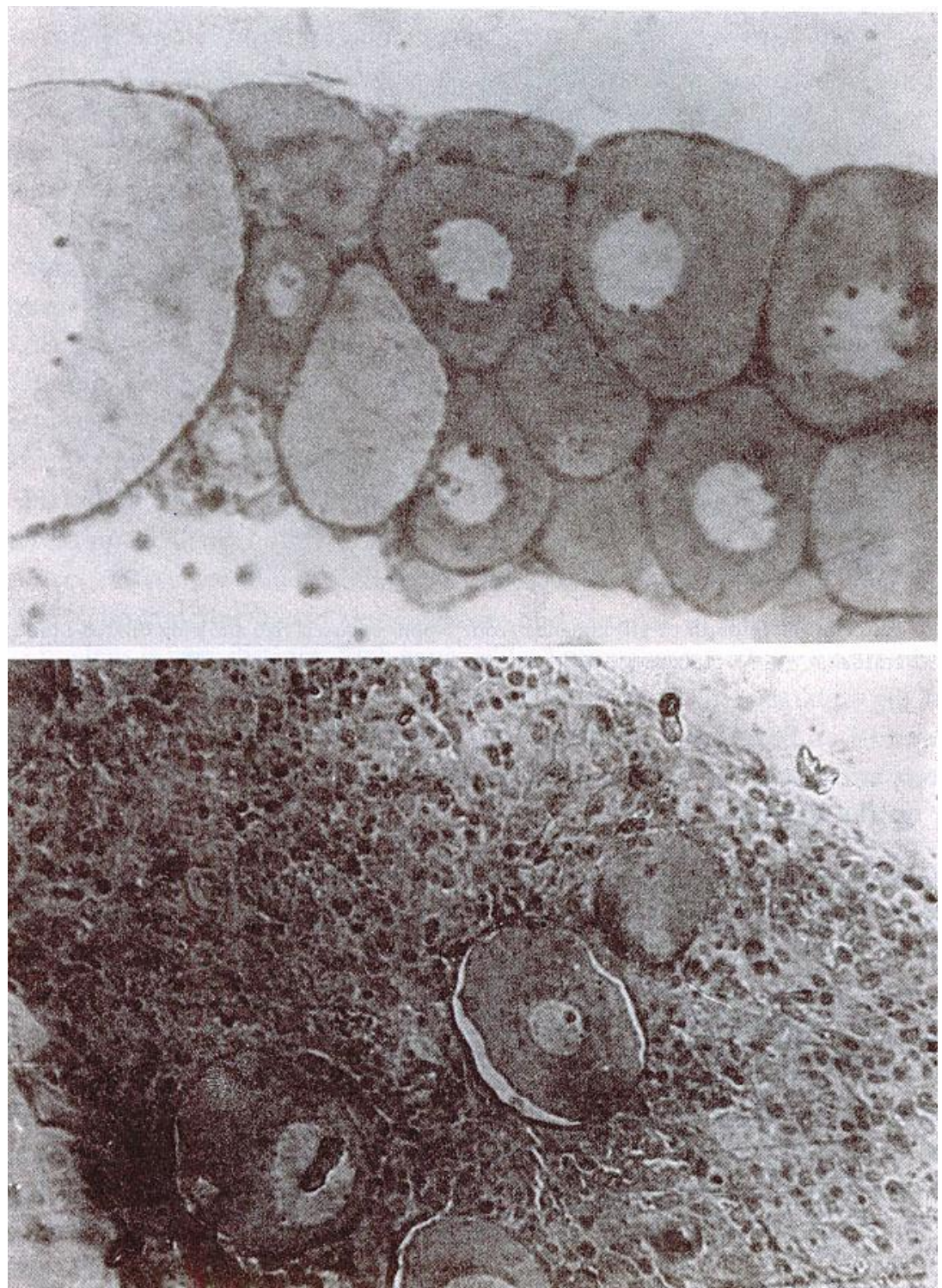

Figure 7. Oocyte growth from 57-day cultured fish (a) Control ovary, (b) Zinc treated fish ovary showing abundant blood cells. X5000. 
Effects of the heavy metal, zinc, on Tilapia nilotica L. - V.S. Cariffo
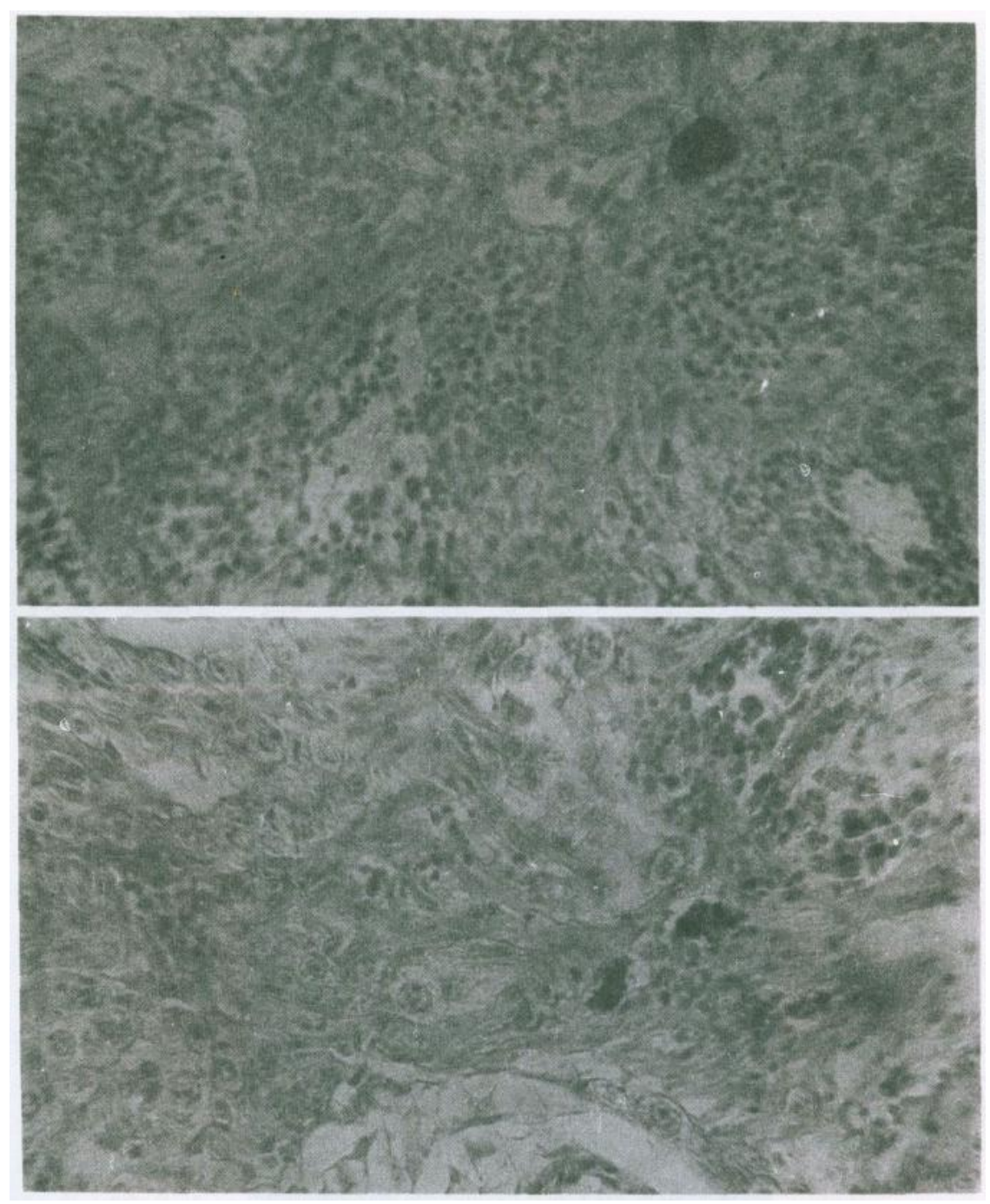

Figure 8. Spermatogenic stages in control juvenile T. nilotica; b. Delay in spermatogenesis in zinc treated fish. $\mathrm{X} 400$. 


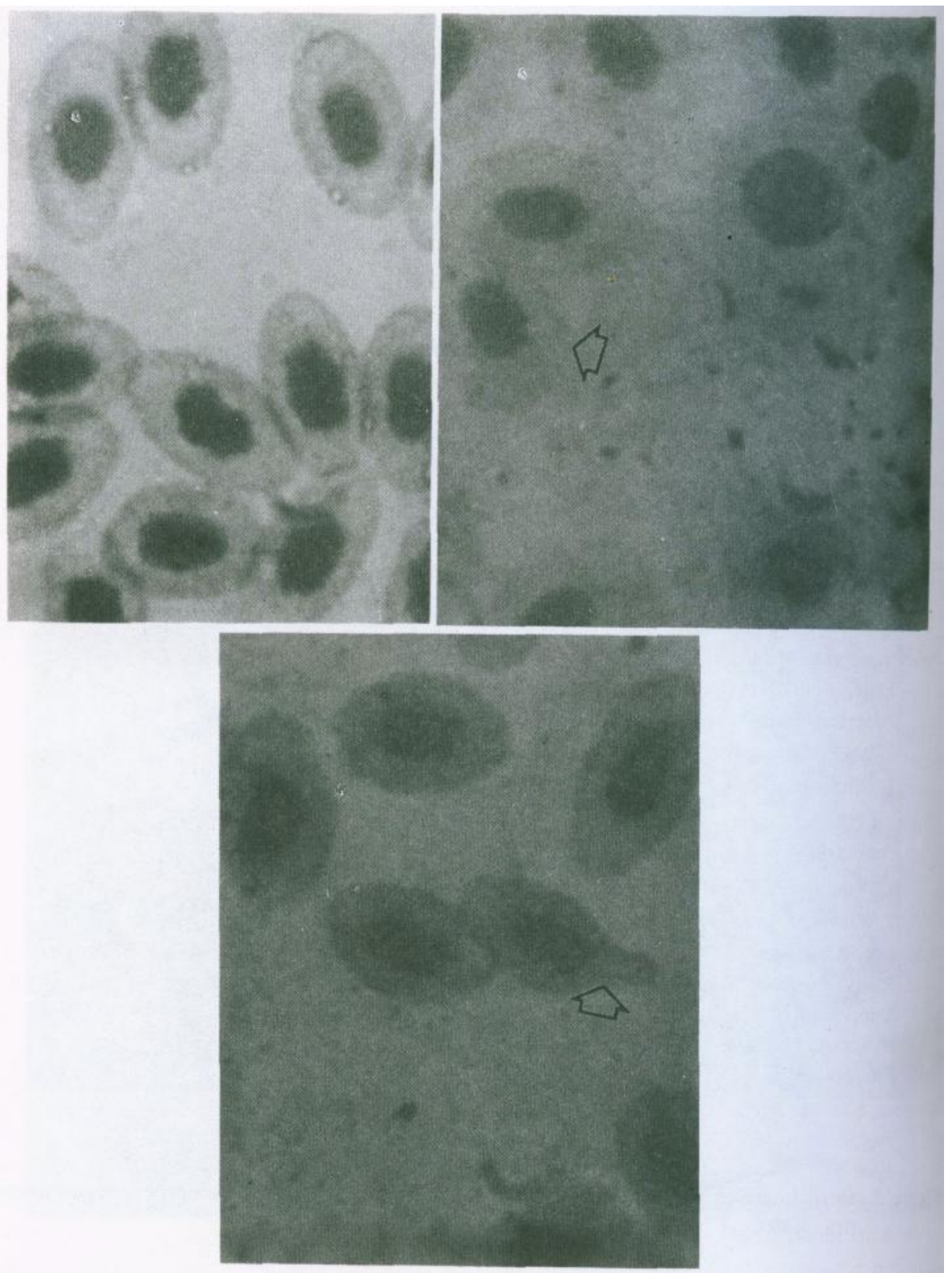

Figure 9. Blood smear from a contol Tilapia nilotica; $b$. Blood smear showing "anisocyclosis", a term applied when the RBCs vary in size (arrow) after exposure to 2, 5, and $10 \mathrm{ppm}$ zinc concentration, c. "Poikilocytosis" exhibited by abnormal variation in shape of RBC after 2, 5, and 10 ppm exposure to zinc. XI000. 
Effects of the heavy metal, zinc, on Tilapia nilotica L. - V.S. Carino

\section{Effects on the Blood}

Anisocytosis and poikilocytosis were noted in the blood smears of zinc-treated fish (9a, b, c). In all zinc treated fish, an increase in hematocrit (\%) was observed at 30 days. With the exception of fish reared at $10 \mathrm{ppm}$ zinc, hematocrit values dropped to control/near control levels after 90 days. Haemoglobin (g/1) content in fish reared in zinc-treated water for 90 days was inversely related to zinc concentration. Exposure of Tilapia nilotica fingerlings for 90 days to zinc concentrations of 5 and $10 \mathrm{ppm}$ induced anemia reducing haemoglobin content of erythrocytes and not by reduced number of erythrocytes.

\section{REFERENCES}

AHUJA S.K. 1970. Chloride cell and mucus-cell responses to chloride and sulphate enriched media in the gills of Gambusia affinis (Baird and Girard) and Cat/a catla (Hamilton). J. Exp. Zool. 173: 231-250.

American Public Health Association, American Water Works Association, and Water Pollution Control Federation 1971. Standard Methods for the Examination of Water and Wastewater. 13th ed., American Public Health Association, NY, USA.

CARIÑO, VIRGINIA S. and ARMANDO G. PUZON, Jr. 1986. Toxic effects of zinc sulphate to Tilapia nilotica L. fingerlings. Natural and Applied Science Bulletin 38(2):127- 134.

CARIÑO, VIRGINIAS. and ARSENIA A. CASAUAY. 1991. The haemocytology of Tilapia nilotica and blood studies on Tilapia nilotica fingerlings after sublethal exposure to zinc. Science Diliman 25(1):6 - 22.

CARIÑO, V.S. and N.C. CRUZ. 1990. Effects of low levels of zinc on the ovarian development of Tilapia nilotica L. Sci. Diliman 3:34-45

CASAUAY, A.A. and CARINO, V.S. 1988. Gonadal sex differentiation in Oerochromis niloticus. In: R.S.V. Pullin, T. Bhukasawan, K. Tonguthai, and J.L. Maclean (eds.). The Second International Symposium on Tilapia in Aquaculture. ICLARM Conference Proceedings, Department of Fisheries, Bangkok, Thailand and International Center for Living Aquatic Resources Management, Manila, Philippines: 121 - 124.

CRESPO, S. 1982. Surface morphology of dogfish (Scyliorhinus canicula) gill epithelium, and surface morphological following treatment with zinc sulphate: As canning electron microscope study. Mar. Biol. 67:159-166.

CRESPO, S. 1984. An in vitro study of the effects of zinc on the osmoregulatory processes. Mar. Pollut. Bull. 15:341-342.

CRUZ, E.R. and G.L. ENRIQUEZ. 1982. Gill lesions associated with acute exposure to ammonia. Nat. Appl. Sci. Bull. 34:1-13.

HESSER, E.F. 1960. Methods for routine fish hematology. Prog. Fish Cult. 22(4):164- 171.

HUGHES, G.M., S.G. PERRY, and V.M. BROWN. 1979. A morphometric study of effects of nickel, chromium, and cadmium on the secondary lamellae of rainbow trout gills. Water Res. 13:665 - 679. 
KARNAKY Jr. K.J., J. KARL, Jr., and W.B. KINTER. 1977. Killifish opercular skin. A flat epithelium with a high density of chloride cells. J. Exp. Zool. 199:355-364.

LEACH, J.M. and A.N. THAKORE. 1973. Identification of the constituents of kraft pulping effluent that are toxic to juvenile coho salmon (Onchorynchus kisutch). J. Fish Res. Board Can. 30:479-484.

NATIONAL EnVIRONMENTAl PROteCtion COUnCIL. 1980. The Philippine Environment. Manila:52-56.

PHILIPPINECOUNCIL for AGRICULTUREand RESOURCES RESEARCH and DEVELOPMENT. 1982. State of the Art Environmental Protection Research: 1 - 11. PUTTE, I.V.D., M.A.

BRINKHORST, and J.H. KOEMAN. 1981. Effecf-of pH on the acute toxicity of hexavalent chromium to rainbow trout (Salmo gairneri). Aquat. Toxicol. 1:129-142.

TUURALA, H. and A. Soivio. 1982. Structural and circulatory changes in the secondary lamellae of Salmo gairdneri after sublethal exposures to dehydroabietie acid and zinc. Aquat. Toxicol. 2:21 - 29. 